\title{
수소생산기술현황
}

\author{
주 오 심† \\ 한국과학기술연구원 청정에너지센터 \\ 136-791 서울특별시 성북구 하월곡동 39-1
}

(2011년 1월 27일, 2011년 2월 18일)

\section{Hydrogen Production Technology}

\author{
Oh-Shim Joo \\ Clean Energy Research Center, Korea Institute of Science and Technology, 39-1 Hawolgok-dong, Seongbuk-gu, Seoul 130-650, Korea \\ (Received 27 January 2011, accepted 18 February 2011)
}

\begin{abstract}
요 약
수소는 에너지를 방출하는 과정에서 부산물로 물만 배출하기 때문에 지속가능한 청정에너지원 중의 하나이다. 현재 세계적으로 사용되는 수소는 대부분 화석연료의 개질에 의해 생산되고 있으며 $1 \mathrm{~kg}$ 수소를 생산하는 과정에서 $7 \mathrm{~kg}$ 이 상의 이산화탄소를 배출하고 있다. 수소를 생산하는 과정에서 투입되는 에너지와 자원이 지속가능하고 재생 가능해야 수소를 청정에너지원이라 할 수 있다. 바이오매스는 화석연료를 대체할 수 있는 에너지원중의 하나인데, 그 이유는 바 이오매스로부터 수소를 생산할 수 있으며 수소생산과정에서 발생하는 이산화탄소는 바이오매스 생산과정에서 소비되 기 때문에 이론적으로 이산화탄소를 발생시키지 않는 에너지원이다. 태양에너지와 물로부터 수소를 생산하는 기술은 지구상에 널려있는 자연에너지와 물을 사용하기 때문에 인류가 직면한 에너지와 환경문제를 해결하기 위한 가장 이상 적인 기술 중의 하나이다.
\end{abstract}

\begin{abstract}
Hydrogen is one of the few long-term sustainable clean energy carriers, emitting only water as by-products during its combustion or oxidation. The use of fossil fuels to produce hydrogen makes large amount of carbon dioxide ( $>7 \mathrm{~kg} \mathrm{CO} / \mathrm{kg} \mathrm{H}_{2}$ ) during the reforming processes. Hydrogen production can be environmentally benign only if the energy and the resource to make hydrogen is sustainable and renewable. Biomass is an attractive alternative to fossil fuels for carbon dioxide because of the hydrogen can be produced by conversion of the biomass and the carbon dioxide formed during hydrogen production is consumed by biomass generation process. Hydrogen production using solar energy also attracts great attention because of the potential to use abundance natural energy and water.
\end{abstract}

Key words: Hydrogen Production, Fossil Fuel Reformin, Biological Hydrogen Production

\section{1. 서 론}

인류는 불을 사용하기 시작하면서 나무나 건초 등을 연료로 사용 하였고, 증기기관의 발명으로 석탄 사용이 가능해졌으며 내연기관 의 발견으로 액체와 천연가스와 같은 기체연료를 사용하기 시작하 였다. 20 세기 후반부터 가속화되기 시작한 연료전지의 개발과 화석 연료 고갈 및 환경오염문제로 인해 청정에너지원인 수소에 대한 관 심이 높아지기 시작하였다. 현재 수소는 원유정제나 암모니아 합성 에 사용되는 중요한 화학원료중의 하나이며 사용되는 대부분의 수 소는 화석연료의 개질에 의해 생산되고 있으나, 물, 석유, 석탄, 천 연가스 및 가연성 폐기물로부터 전기, 열, 미생물 등의 에너지를 공 급하여 제조할 수도 있다. 수소는 연소과정에서 온실가스인 이산화

\footnotetext{
${ }^{\dagger}$ To whom correspondence should be addressed.

E-mail: joocat@kist.re.kr

\$이 논문은 KAIST 임선기 교수님의 정년을 기념하여 투고되었습니다.
}

탄소를 배출하지 않는 청정에너지이며 원유와는 다르게 이차 에너 지원이다. 이차 에너지원인 수소를 제조하는 과정에서 원료나 에너 지원에서 온실가스가 배출된다면 수소를 청정에너지원이라 하기 어 렵다.

전 세계적으로 연간 생산되는 수소는 7,000억 $\mathrm{NM}^{3}$ 이며(국내 생 산량은 80 억 $\mathrm{NM}^{3}$ ) 이것은 600 백만대 이상의 연료전지 자동차에 사용할 수 있는 양이다. 수소생산에 사용되는 원료로는 천연가스가 약 $50 \%$, 원유 약 $30 \%$, 석탄과 물 등으로 이루어져 있다. 대부분의 수소는 사용되는 지점에서 생산되고 있으며, 생산된 수소의 약 $50 \%$ 는 암모니아 합성에 사용되고 약 $30 \%$ 는 원유정제에 이용되고 있다. 수 소생산가격은 원료가격에 영향을 받으며 2030까지 예상되는 가격 범위는 8 12 ct $/ \mathrm{kWh}\left(2.6 \sim 4.0 \$ / \mathrm{kg} \mathrm{H}_{2}\right)$ 이다. 수소의 수송비용은 수송 해야하는 수소의 양과 거리에 영향을 받으며 그 가격범위는 1 4 ct/ $\mathrm{kWh}\left(0.3 \sim 1.3 \$ / \mathrm{kg} \mathrm{H}_{2}\right)$ 로 알려져 있다. 많은 양의 수소를 먼 거리로 수송할 경우 파이프라인이 유리하며 유럽일부(벨기에, 프랑스, 네델 
란드, 독일)와 미국해안 지역에서는 파이프라인을 통해 수소를 수 송하고 있는데 현재, 전 세계적으로 $16,000 \mathrm{~km}$ 이상의 파이프라인 이 설치되어 있다. 예상되는 수소공급비용은 $10 \sim 16 \mathrm{ct} / \mathrm{kWh}(3.6 \sim 5.3 \$$ / $\mathrm{kg} \mathrm{H}_{2}$ )이며 이 중 수소생산비용이 60 80\%를 차지하며 station 설치 에 $10 \%$ 액화와 운송에 나머지 비용이 사용될 것이다.

에너지순환을 살펴보면 화석연료가 산소와 반응하여 에너지를 공 급하면서 이산화탄소와 물을 방출하게 된다. 세계적인 인구 증가와 경제발전에 따라 에너지 사용 양이 크게 증가하면서 대기중으로 배 출되는 이산화탄소의 양이 자연이 처리할 수 있는 한계를 넘게 되 어 온실가스효과를 통해 환경문제를 유발하게 되었다. 또한 가까운 미래에 인류의 에너지원인 화석연료의 고갈이 예측되기 때문에 재생 에너지를 이용한 에너지원 개발에 대한 관심이 크게 증가하고 있다. 현재 산업용, 전력용, 가정용, 수소용으로 사용되고 있는 대부분의 동 력원이 화석연료 기반으로 작동되고 있으나 20세기 후반부터 집중되 기 시작한 연료전지 개발로 연소(산화) 후 에너지를 공급하면서 물 이 외에 환경오염 유발물질을 배출하지 않는 수소에 대한 관심이 크게 증가하고 있다. 화석연료의 가장 큰 장점은 가격이 저렴하고 저장과 운반이 용이하다는 것이다. 재생에너지원으로부터 대체에너지원 개 발이 성공하려면 화석에너지가 가지고 있는 이 장점들을 극복할 수 있는 대안 기술이 필요하지만 현재까지는 개발되지 못하고 있다.

현재 대부분의 수소는 화석연료인 천연가스, 석유/잔사유, 석탄의 수증기개질, 열분해, 가스화를 통해서 생산되고 있으며 태양광이나 풍력을 통한 물분해, 광을 이용한 물의 직접분해, 생물학적, 유기성 폐기물로부터 수소생산 또는 원자력에너지를 이용하여 물을 열화학 분해 하거나 고온전기분해를 통해 수소를 생산하는 연구들이 있다. 화석연료를 이용하는 기술들은 대부분 상용공정으로 운영되고 있으 며 대체에너지를 이용한 공정들은 연구단계에 있다. 현재는 기술이 성숙된 상용공정을 통하여 생산된 수소가 이용되고 있으나 장기적 으로는 대체에너지를 이용한 수소생산 기술이 현재의 상용공정을 대체할 것으로 기대된다. 그러나 그 시점이 언제인지를 예측하기는 쉽지 않다. 현재, 원유와 가스가 세계 1 차 에너지수요의 $80 \%$ 정도 를 담당하고 있으며 원유에 대한 세계적 수요는 중국등 고속성장국 가에서의 수요증가로 가속화되고 있다. 원유가격이 계속해서 높게 유지된다면 2030년경에는 GTL(Gas-to Liquid)이나 CTL(Coal-toLiquid)와 같은 기술들이 개발되어 그해에 예상되는 원유생산량의 6 13\%정도를 감당할 수 있을 것이고 일부는 오일샌드에서 공급될 것이다. 수소경제 시대 도래에 관한 시나리오에 따르면 2050년의 수소경제 상황을 정확하게 예측하기는 어렵지만 수소수요는 화석연 료의 고갈 정도에 따라 크게 영향을 받을 것이라는 것은 분명하다.

\section{2. 화석연료개질}

석탄, 천연가스, biomass 등을 $700 ~ 1,100{ }^{\circ} \mathrm{C}, 3 \sim 25 \mathrm{bar}$ 의 조건에서 증기개질, 건조개질 (dry reforming), 부분산화반응을 통해 $\mathrm{CO} / \mathrm{CO}_{2} /$ $\mathrm{H}_{2}$ 혼합가스를 생산하며 수성가스반응 $\left(\mathrm{H}_{2} \mathrm{O}+\mathrm{CO} \Leftrightarrow \mathrm{CO}_{2}+\mathrm{H}_{2}\right)$ 을 이 용해 $\mathrm{H}_{2} / \mathrm{CO}$ 의 비율을 조절하고 이를 통해 얻어진 합성가스는 촉매 반응을 이용하여 메탄올, DME(dimethyl ether) Fischer-tropsch, $\mathrm{H}_{2}$, oxoalcohol, 개미산 등의 생산에 사용된다. Table 1 은 화석연료로부 터 수소를 생산할 때 배출되는 합성가스에서 수소대비 이산화탄소 의 비율을 보여준다. Table 1 에서 보면 천연가스 수증기 개질이 이 산화탄소를 가장 적게 배출하는 공정기술이며 부분산화법이 상대적
Table 1. $\mathrm{CO}_{2} / \mathrm{H}_{2}$ ratio in gas products of reforming processes

\begin{tabular}{cc}
\hline \hline $\mathrm{CO}_{2} / \mathrm{H}_{2}$ & Reforming Technology \\
0.25 & Methane Steam Reforming \\
0.31 & Pentane Steam Reforming \\
0.33 & Methane Partial Oxidation \\
0.59 & Heavy oil Partial Oxidation \\
1 & Coal Partial Oxidation \\
\hline
\end{tabular}

으로 더 많은 이산화탄소를 생성하는 것을 알 수 있다. 수소생산 비 용은 대규모증기개질의 경우 가장 저렴하며 현지에서 증기개질을 하여 소비지로 수소를 이송할 경우 그 비용이 증가한다. 연산 100,000 만톤 규모의 증기개질기 하나로 약 100 만 대의 연료전지 자 동차를 운행할 수 있다. 수소는 2차 에너지로 생산, 가공처리, 저장, 운반에 드는 에너지가 과도하여 수소생산에만 1.2 1.4배의 에너지 가 소요되고 석유의 경우는 $8 \%$ 정도의 비용이 요구된다.

천연가스에서 수소를 생산하는 재래방식의 기술은 증기개질, 비 촉매 부분산화, 자열개질, $\mathrm{CO}_{2}$ 개질, 직접분해가 있으며 첨단방식 으로는 촉매부분산화, 플라즈마 촉매개질, 흡착부과 반응 등이 있다. 증기개질의 경우 $800 \sim 900{ }^{\circ} \mathrm{C}$ 온도에서 운전되며 수율은 $75 \%$ 정도 인 복잡한 공정이지만 세계적으로 400 기 정도가 상용공정으로 운 영되고 있다. 부분산화의 경우 $1,100 ~ 1,200{ }^{\circ} \mathrm{C}$ 에서 운전되며 공기 를 사용할 경우 $\mathrm{NO}_{x}$ 와 soot이 발생되어 공해를 유발하지만 에너지 효율이 높은 기술이다. 플라즈마 개질의 경우 $2,000{ }^{\circ} \mathrm{C}$ 온도에서 운 전되며 수율은 $95 \%$ 정도로, $\mathrm{H}_{2} / \mathrm{CO}$ 만이 생성되고 소형화, 이동형 액체연료 사용이 가능한 신기술인 것이 특징이다.

전 세계적으로 생산되는 수소의 약 $50 \%$ 를 제조하는 메탄 수증기 개질공정을 간단하게 정리하면 Fig. 1과 같다. 원료인 천연가스에는 수량의 경질탄화수소와 미량 $(\mathrm{ppm})$ 의 황화합물이 포함되어 있다. 이 원료를 개질기에 주입하기 전에 유황성분의 농도를 $0.2 \mathrm{ppm}$ 단위로 낮추기 위해 수소화탈황 및 $\mathrm{ZnO}$ 를 이용한 흡수공정이 필요하다. 반 응은 대개 $350 \sim 400^{\circ} \mathrm{C}$ 의 온도와 상압 70 기압의 조건에서 수행되 며 촉매로는 알루미나에 담지된 $\mathrm{Co}-\mathrm{Mo}$ 가 사용된다. 탈황공정을 거 친 원료가스는 개질기로 주입되는데 상용공정에서는 주로 Calcium aluminate ceramic 지지체에 담지된 ICI의 니켈산화물을 개질촉매

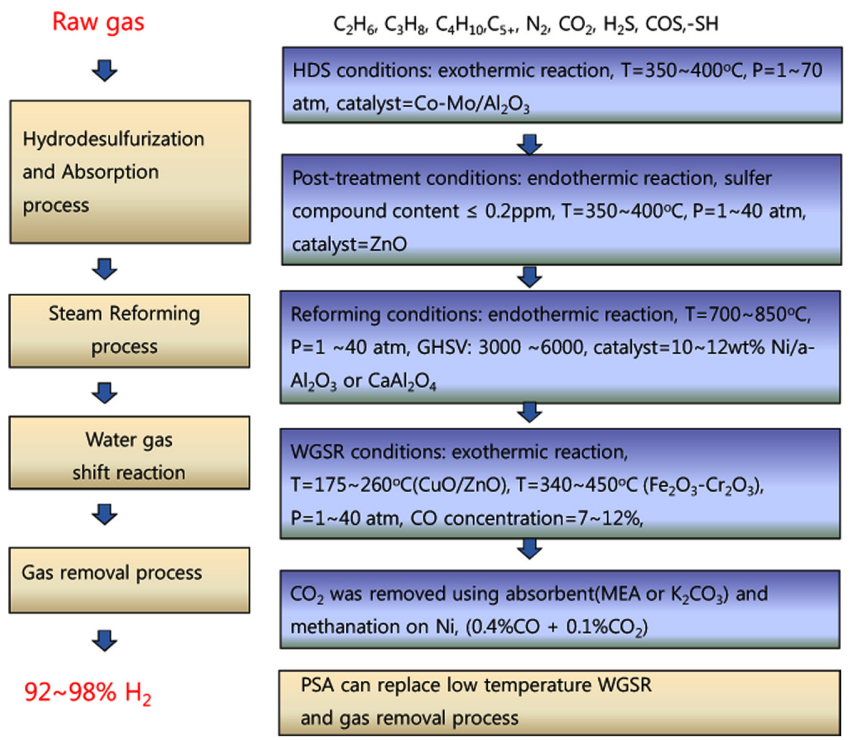

Fig. 1. Flow sheet of $\mathrm{CH}_{4}$ steam reforming process. 
로 사용하고 있다. 수증기 개질공정은 반응식 (1)과(2)에 의해 진행 되는 반응으로 메탄 1 몰당 생산되는 수소의 수율이 가장 높은 경제 적인 공정이다. 그러나 평형반응으로 반응속도가 느리기 때문에 공 정규모가 커야하며 부하변동에 대한 정상상태로의 등답 특성이 느 린 단점이 있다.

반응식(1) $\mathrm{CH}_{4}+\mathrm{H}_{2} \mathrm{O} \rightarrow \mathrm{CO}+3 \mathrm{H}_{2}, \Delta \mathrm{H}=+49.7 \mathrm{kcal} / \mathrm{mol}$ 반응식(2) $\mathrm{CO}+\mathrm{H}_{2} \mathrm{O} \rightarrow \mathrm{CO}_{2}+\mathrm{H}_{2}, \Delta \mathrm{H}=-10.0 \mathrm{kcal} / \mathrm{mol}$

개질반응은 강한 흡열반응으로 고온 및 저압조건에서 정반응으 로의 진행이 유리하고, 수성가스 전환은 온화한 발열반응으로 저온 조건이 유리하며 압력에 대한 영향은 무시할 만하다. 대개는 개질 반응 후에 $\mathrm{CO}$ 의 농도를 7 12\%로 고온과 저온 수성가스 전환반응 (반응식(2))을 이용하여 $\mathrm{CO}$ 의 농도를 줄여준다. 수성가스전환공정 을 거친 가스에서 $\mathrm{CO}_{2}$ 의 농도는 $20 \%$ 정도이나 흡수제를 이용하여 제거하고 나면 $\mathrm{CO} 0.4 \% \mathrm{CO}_{2} 0.1 \%$ 함량의 가스가 얻어지며 메탄 화를 통해 후속공정의 촉매독으로 작용하는 $\mathrm{CO}$ 를 제거하게 된다. 이런 다양한 공정을 거쳐 $92 \sim 98 \%$ 농도의 수소가 생산된다. PSA법 을 적용하면 저온 수성가스반응, $\mathrm{CO}_{2}$ 흡수, 메탄화 공정을 사용하 지 않고도 높은 순도의 수소를 얻을 수 있는 장점이 있다.

메탄 수증기개질 공정외에도 부분산화법, 플라즈마(저온, 고온 플 라즈마) 이용 천연가스분해 수소제조, 자열개질(Auto-thermal reforming), $\mathrm{CO}_{2}$ 개질, 직접분해(direct cracking), 흡착부과반응개질 (Sorption enhanced reaction process) 공정등이 있으며 각 공정별로 각기 장단점을 가지고 있고 원료의 조건이나 수소 사용조건에 따라 각 공정을 선택적으로 적용할 수 있다.

화석연료개질 연구동향을 살펴보면 현재 대체에너지원을 이용하 여 수소를 생산하려는 다양한 기술들이 연구되고 있으나 화석연료 가 가지고 있는 장점을 극복하기가 쉽지 않아 상당기간 동안 화석연 료 개질공정을 통해 제조된 수소가 공급될 것으로 예상되고 있다. 수증기 개질의 상용공정은 대개 30 50만 톤 규모로 운영되고 있으 며 기술의 성숙도가 아주 높고, 현재는 니켈 촉매의 성능 및 안정성 을 높이기 위한 공정개선연구들이 진행되고 있다. 정치형 연료전지 에 수소를 공급하기 위한 연료개질기 시스템개발이 진행되고 있으 며 이 경우 요소기술 및 시스템통합을 통한 소형화, 고효율화, 저비 용생산을 목표로 연구개발이 진행되고 있으며 균일가열기술, 소형 열교환기기술, 저온 활성촉매 개발 등이 중요한 요소기술이다. 부분 산화의 경우 고순도 산소를 이용하는 기술이 개발되고 있으며 이를 위해 PSA법 및 세라믹분리막 기술개발이 진행되고 있고, 공기를 사 용하는 공정에서는 탄소침적방지 촉매개발이 진행되고 있다. 플라 즈마 개질의 경우 반응물과 공기와의 열교환을 극대화하기 위한 소 형 고효율 열교환기개발이 진행되고 있다. 자열개질의 경우 고순도 산소이용기술이 개발되고 있으며 부분산화 개질과 같이 PSA법 및 세라믹분리막기술 개발이 진행되고 있다. 또한, $\mathrm{CO}_{2}$ 개질의 경우 탄소침적방지 및 고활성촉매 개발이 진행되고 있으며 직접분해의 경우 촉매-카본분리단위공정, 촉매재생 및 재순환 단위공정기술개 발 등이 진행되고 있다.

\section{3. 생물학적 수소생산기술}

생물학적 수소생산 기술은 다양하여 기질로 사용되는 원료 물질 에 따라 물, 유기물, 가스로 크게 구분되며, 작용하는 미생물의 다

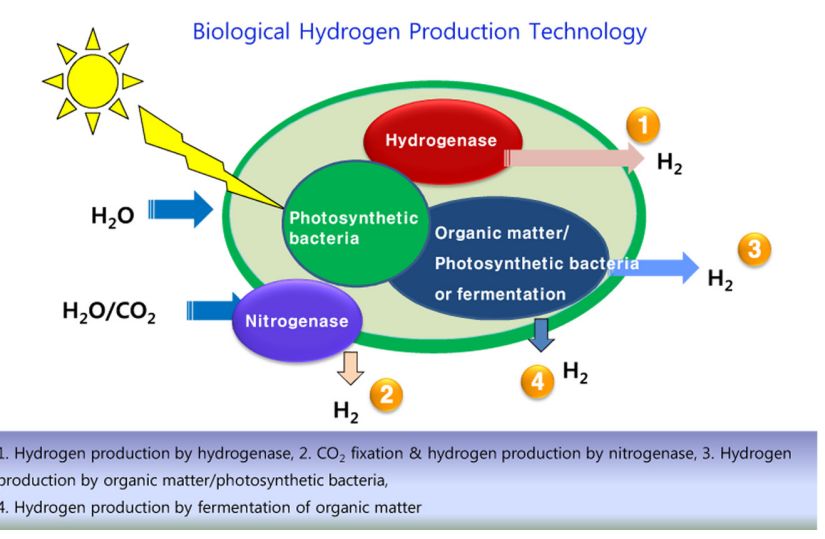

Fig. 2. Biological hydrogen production.

양한 기작에 따라 여러 가지 기술이 알려져 있다. 지금까지 발표된 다양한 기술들을 매우 간단하게 정리한 것이 Fig. 2이다.

Fig. 2의 1번 경로는 녹조류(green algae)가 빛을 흡수하여 물로 부터 양성자와 전자를 공급받아 수소를 생산하는 직접 물분해(direct photolysis) 수소생산을 나타내며, 2 번 경로는 질소고정효소에 의한 광합성작용으로 물을 분해하여 산소를 발생하고 동시에 공기중의 이산화탄소를 고정하며 수소를 발생하는 효소관여 수소생산(indirect photolysis or two-stage photolysis), 3 번 경로는 유기물로부터 purple non-sulfur 박테리아의 광합성발효에 의한 수소생산(Photo-fermentation), 4번 경로는 광이 존재하지 않은 조건에서 혐기 미생물에 의해 유기 물자체가 에너지원으로 사용되는 발효에 의한 수소생산(dark fermentation)을 나타낸다. 태양광을 이용하고 유기성 폐자원으로부 터 수소를 생산할 수 있는 생물학적 방법은 신에너지를 생산할 수 있는 기술로 평가되고 있다. 광합성 미생물은 태양광을 에너지원으 로 이용하여 물이나 유기물을 분해시켜 수소를 발생시키는데 미생 물 내부에는 자가 증식형 수소생산 기작이 내장되어 있어 별도의 태 양광전환 장치가 불필요하다. 바이오매스 원료는 도처에 무한정으 로 존재하고 자연계에서 계속 합성되고 있다. 따라서 광합성 미생 물에 의한 수소생산은 화석연료의 대체 효과뿐만 아니라 폐기물과 폐수의 처리, $\mathrm{CO}_{2}$ 배출감소에 따른 온실효과 완화 등이 가능하여 에너지확보와 지구환경보호에 큰 역할을 할 것으로 기대된다.

미생물이 수소를 발생하는 현상은 오래전에 알려졌으나, 미생물을 이용한 수소생산 가능성에 대한 연구는 1970년대 에너지위기 발생 후 본격적으로 시작되었다. 식물이나 조류는 내재되어 있는 광합성 기작에 의해 물로부터 산소와 환원체를 만드는데, 이렇게 만들어진 환원체는 수소생산을 유도하는 효소가 존재하지 않는 식물의 경우 이산화탄소를 탄수화물로 전환하고 조류의 경우는 이산화탄소를 고 정함과 동시에 양성자(proton)를 수소로 환원할 수 있다. 생물학적으로 물을 직접 광분해하는 반응에서 물에서 오는 전자는 광계II(photosystem II)와 광계I(photosystem I)을 차례로 거치면서 전자전달체인 페레독 신(Ferredoxin(FD))을 거쳐 수소화효소(hydrogenase)로 전달된다. 물에서 직접 수소를 발생하는 조류의 광합성 기작은 일시적으로 일 어나는 현상으로 대부분의 조류는 암.혐기 조건에서 적응하는 동안 소량의 수소를 발생하고 난 후 일정기간이 지나면 곧 정상적인 광 합성작용에 의해 이산화탄소를 고정하면서 산소를 배출하게 된다. 직접광분해에 의해 물로부터 수소를 발생하는 수소화효소는 광합성 과정에서 생산되는 산소에 의해 쉽게 그 활성을 잃게 되어 정상적 인 광합성이 진행되면 수소의 발생이 멈추게 되는 것이다. 물을 미 
Table 2. The paths of biological hydrogen production

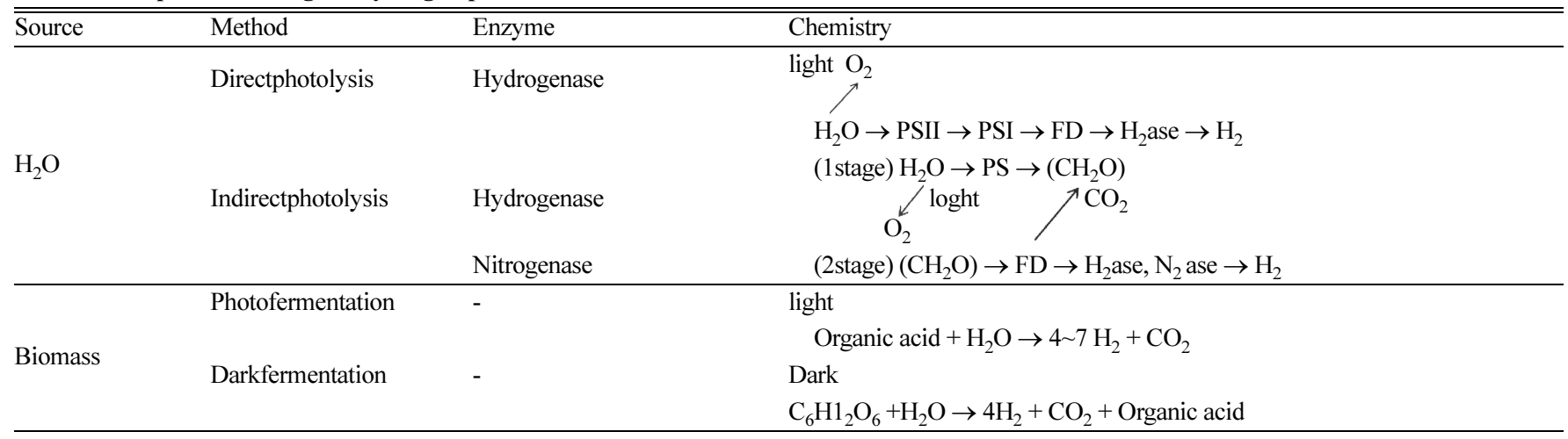

생물을 이용하여 광분해하여 직접 수소를 대량생산할 수 있는 방법 이 개발된다면 물과 태양광만으로 수소를 생산할 수 있는 이상적인 에너지생산 기술이지만 극복해야 할 문제점이 많은 분야이다. 즉, 미 생물이 태양에너지를 최대로 변환할 수 있는 높은 광 효율과 수소생 산효소의 산소독성극복 및 전자전달능이 개선되어야 한다. Table 2에 서는 Fig. 2에서 설명한 네 가지의 생물학적 수소생산 반응식을 나타 내고 있으며 그 첫 번째가 직접 물분해 수소생산 반응경로이다.

간접 광합성 수소생산은 이산화탄소를 중간 전자전달체로 이용 하여 광합성과 수소생산반응이 분리된 경로로 진행되는 기술이다. 1 단계로 공기중 이산화탄소를 고정하여 탄수화물을 축적하고 2단계 에서 암·혐기 조건의 발효조에서 수소화효소를 활성화하여 일부 수 소를 발생시키고 다시 빛 에너지를 공급하여 1단계에서 축적된 탄 수화물로부터 혐기조건에서 질소고정효소(Nitrogenase)에 의해 수 소생산을 극대화하는 것이다. 이 과정에서 조류 등 한 개의 미생물 을 적용할 경우 혐기적으로 활성화된 수소화효소가 반응 1,2 단계에 관여하게 된다. 이것은 소비에너지가 비교적 적은 경제적인 반응으 로 알려져 있으나 실질적인 적용가능성은 아직 분명하지 않은 부분 이 많다.

광합성세균 중 Purple non-sulfur 박테리아는 혐기조건에서 장파 장의 빛과 유기산을 환원체로 이용하여 수소를 생산한다. 광합성세 균은 자체 안테나를 이용해 장파장의 빛을 흡수하여 질소원이 존재 할 때는 질소고정화효소에 의해 질소고정을 하고, 질소원이 존재하 지 않을 때는 양성자를 환원하여 수소를 발생한다. Purple nonsulfur 박테리아는 수소화효소보다는 질소고정효소를 이용한 광합 성기작에 의해 수소를 생산하며 필요한 양성자와 전자는 유기물이 나 환원 황화합물, 분자상의 수소로부터 얻는다. 이런 방법에 의한 수소생산은 혐기, 적절한 광도 및 제한된 질소원 및 효율적인 기질 의 공급을 통해 수소생산 속도를 극대화할 수 있는데 미생물에 따 라 그 최적조건에는 차이가 있다. 유기물질 중에서도 유기산은 탄 소원 및 전자공여체로 높은 수소생산성을 나타내는 기질이다. 광합 성박테리아는 대사적인 다양성을 나타내어 호기 및 혐기 암조건에 서도 성장과 광합성을 할 수 있고, 동시에 발효에 의해서도 배양이 가능하다고 알려져 있다. 이러한 다양성 때문에 기질이용 효율차이 는 있지만 단당류, 이당류 및 각종 유기산을 모두 배양기질로 사용 할 수 있다.

수소생산 박테리아는 광이 없는 혐기발효 조건에서 바이오매스 등의 유기물을 이용하여 배양액 중에 각종 유기산, 유기용매를 축 적하고 동시에 수소와 이산화탄소를 발생한다. 생성되는 발효산물 의 종류와 비율은 초기 배양조건인 산도, 온도 기질의 종류와 농도,
무기물의 농도에 영향을 받으며, 발효과정에서 생성된 대사산물인 유기산과 유기용매에 의해서도 영향을 받는다. 혐기발효에 의해 2 몰의 초산과 최대 4 몰의 수소가 생산된다. 이것은 glucose 1 몰로부 터 생산할 수 있는 12 몰의 수소중 $33 \%$ 정도이지만, 동시에 생성된 아세테이트는 광합성 수소생산 기질로서 적당한 광조건과 광합성박 테리아에 의해 높은 효율로 수소를 생산할 수 있다. 이론적으로 glucose 1몰로부터 12몰의 수소를 생산할 수 있지만 실질적으로 수 소생산 중에 발생하는 산도변화, 유기산 생성율은 수소생성 효율에 큰 영향을 주고, 제당 식품 폐수를 이용할 경우 이종의 박테리아나 폐수 중에 존재하는 금속이온 및 질소원 등 또한 수소생산 효율에 영향을 준다. 따라서 기질로부터 수소발생과 동시에 유기산의 축적 을 최대화 할 수 있는 발효조건의 최적화는 생물학적 수소생산 공 정의 주요변수이다.

생물학적 수소생산에는 시아노박테리아, 혐기성 및 발효성 박테 리아를 사용하는데 그중에서도 발효성 박테리아를 이용한 수소생산 가능성이 가장 높고 그 결과는 Table 3에서 잘 보여주고 있다. Table 3 은 네 가지의 생물학적 수소생산 기술을 이용하여 얻을 수 있는 수 소생산 속도를 나타내고 있으며 암 발효가 가장 높은 수소생산 속 도를 보여주는 것을 알 수 있다. 또한, 암 및 광 발효를 두 단계의 하이브리드 시스템으로 결합시키면 수소생산 수율을 개선시킬 수 있다. 먼저 협기성 박테리아가 포도당 또는 전분을 초산 발효대사 작용에 의해 분해하면 두 번째 반응기에서 광합성박테리아가 이를 수소로 전환하게 된다. Fig. 3은 이와 같은 하이브리드 시스템의 개 념도로서, 먼저 미세조류를 이용하여 이산화탄소를 고정해서 탄화 수소를 만들고 이 바이오물질을 발효하면 수소가 발생하며 유기산 등이 남게 되는데 미세조류는 필터링하여 광합성조로 보내고 남은 유기산을 광 발효시키면 수소가 생산된다.

생물학적 수소생산의 연구현황을 살펴보면 다음과 같다. 일본에 서는 1991 1999년에 환경조화형 수소제조 기술개발(NEDO)이 진 행되었고 혐기 및 광합성박테리아를 이용한 유기폐기물로부터 수소 생산을 연구하였다. 연구결과들은 Ishikawajima-Harima 중공업, Kubota Corp.에서 유기폐기물의 전처리 및 효율적 발효, 광반응기

Table 3. $\mathrm{H}_{2}$ production rate of bio- $\mathrm{H}_{2}$ system

\begin{tabular}{lc}
\hline \hline Bio hydrogen production & $\mathrm{H}_{2}$ production rate \\
\cline { 2 - 2 } & $\left(\mathrm{mmol} \mathrm{H}_{2} / \mathrm{L} . \mathrm{h}\right)(\mathrm{cc} / \mathrm{L} . \mathrm{h})$ \\
\hline Direct photolysis & $0.07(1.56)$ \\
Indirect photolysis & $0.355(7.95)$ \\
Photo fermentation & $0.16(3.584)$ \\
Dark fermentation & $8 \sim 121(180 \sim 2,700)$ \\
\hline
\end{tabular}




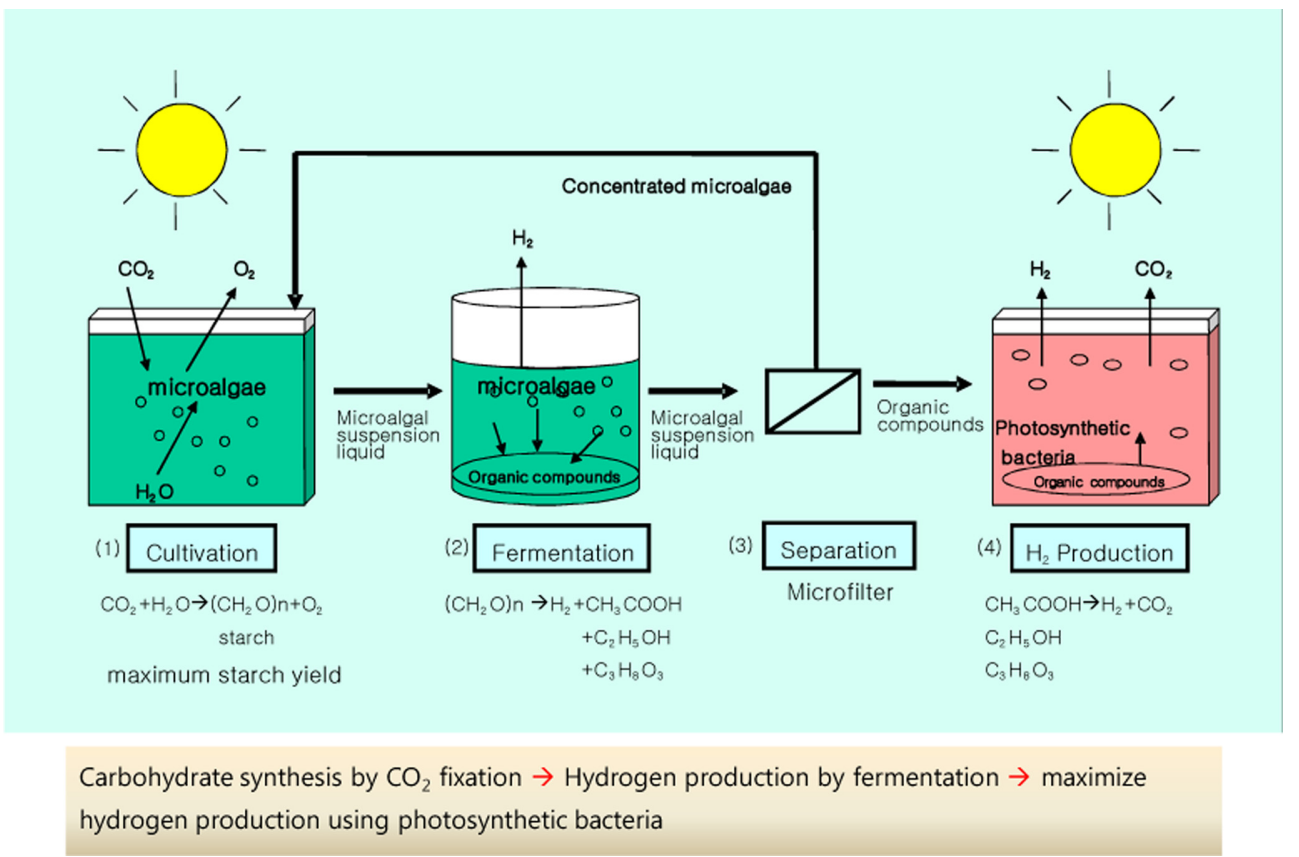

Fig. 3. Hybrid system of Photo- and dark fermentation.

설계등에 적용되었고, Kansai 발전소의 경우: 조류와 광합성 박테 리아를 조합한 $1,100 \mathrm{~L}$ 공정운전을 시도하였다. 독일에서는 수소생 산 미생물의 생물학적, 생리적, 유전공학적 연구를 주로 진행하였으 며 아헨공대와 ISA-tec에서는 광합성박테리아를 이용하여 $2 \mathrm{~L} / \mathrm{h} \cdot \mathrm{m}^{2}$ 수소생산을 시도하였고 수소생산비용은: $25 \mathrm{DM} / 100 \mathrm{Kw} \cdot \mathrm{hr}(=150$ 원/ kW.hr)로 발표되었다. 미국에서는 DOE의 지원을 받은 national renewable energy Lab., Oak Ridge national Lab., Hawaii 대학 등에서 수소생산을 연구하였으며 광합성생물반응기(230Liter)를 이용한 수 소생산결과를 발표하였다. 한국에서는 교과부의 지원으로 에너지기 술연구원을 주축으로 태양광이용 생물학적 물분해 수소생산기술에 대한 연구가 진행되고 있다(2000 2013).

\section{4. 열화학싸이클에 의한 수소생산}

물을 직접 열분해하기 위해서는 $3300 \mathrm{~K}$ 이상의 열원이 필요하고 직접열분해의 경우 $1 \mathrm{bar}$ 의 압력에서 약 $64 \%$ 의 전환율로 수소를 생 산할 수 있다. 직접열분해의 경우 높은 온도도 문제이지만 반응기 재질도 큰 어려움이다. 또한, $\mathrm{H}_{2} / \mathrm{O}_{2}$ 가 혼합되어 있어 세라믹 막을 이용한 고온 분리가 요구되는데 재질에 대한 한계 때문에 가까운 장 래에 경제성을 맞추기 어렵다. 직접열분해가 갖는 수소/산소 고온 분리 및 재질에 대한 문제점을 해결하기 위해 금속 산화물을 이용 한 다단계 열화학싸이클을 이용하여 물로부터 수소를 생산할 수 있 다. 열화학 싸이클을 이용할 경우 물의 산화, 환원 반응이 분리되어 일어나기 때문에 수소와 산소의 추가 분리가 필요하지 않다. 열화 학싸이클은 물분해를 비교적 낮은 온도 $(1,300 \mathrm{~K})$ 의 화학반응들로 구성하여 전체적으로 폐 싸이클(close cycle)이 되도록 구성되어 있 다(Fig. 4). 열원으로는 고온의 가스로, 집열된 태양열 및 핵반응로 가 가능하며 흡열반응에 필요한 열과 발열을 상쇄하면 이론상 전기 분해법보다 높은 열효율을 얻을 수 있으므로 1967 이후 200개가 넘 는 싸이클이 제안되었다.

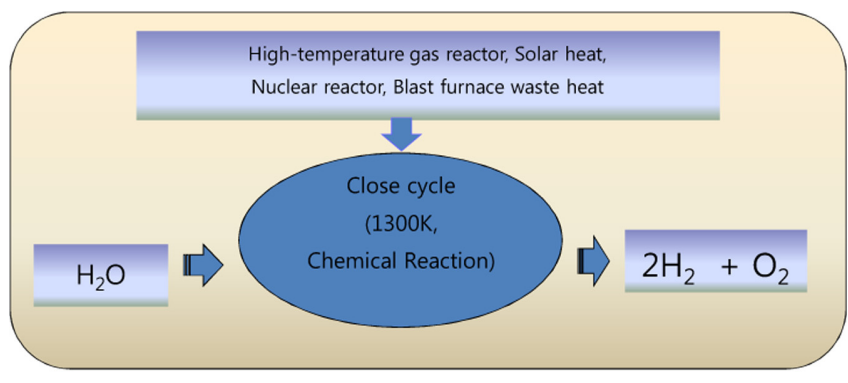

It is possible to operate with a completely closed system and produce clean, sustainable $\mathrm{H}_{2}$. There is no emission of wastes and $\mathrm{CO}_{2}$. USA, Germany, Swiss, Japan.

Fig. 4. Thermochemical cycle.

열화학싸이클은 다단계의 화학반응을 조합시켜 반응물질이 순환 매개 물질로 순환하면서 열적으로 물을 분해하는 방법으로 보통 $1,300 \mathrm{~K}$ 이하의 화학반응들로 구성되어 있다. 열화학싸이클 공정의 기본반응은 다단계를 거치지만 전체반응은 수소와 산소만 생성한다. 환원제로는 금속성분인 $\mathrm{Fe}$ 를 사용한 예가 가장 많으며 비금속 성분 으로 가장 사용빈도가 높은 것으로는 황, 염소, 탄소등이다. 미국, 독일, 일본을 중심으로 열화학싸이클 연구가 계속되었으며, 최근에 는 금속산화물을 이용한 2단계 열화학싸이클에 대한 연구가 진행되 고 있다.

태양열을 이용한 2단계 열화학싸이클의 단계별 반응식들은 다음 과 같다.

$2 \mathrm{H}_{2} \mathrm{O}+$ Solar energy(thermal energy) $\rightarrow 2 \mathrm{H}_{2}+\mathrm{O}_{2}$ (Net reaction)

$\mathrm{M}_{x} \mathrm{O}_{y}+$ thermal energy $\rightarrow \mathrm{M}_{x} \mathrm{O}_{y-z}+\mathrm{z} / 2 \mathrm{O}_{2}$ (산소발생)

$\mathrm{M}_{x} \mathrm{O}_{y-z}+\mathrm{zH}_{2} \mathrm{O} \rightarrow \mathrm{M}_{x} \mathrm{O}_{y}+\mathrm{zH}_{2}$ (수소생성)

$\mathrm{Fe}_{3} \mathrm{O}_{4} / \mathrm{FeO}(>2,500 \mathrm{~K})$ 나 $\mathrm{ZnO} / \mathrm{Zn}(>2,273 \mathrm{~K})$ 를 산화, 환원쌍으로 이용한 열화학싸이클의 경우 상당히 높은 온도가 요구되고, $\mathrm{ZnO}$ / 
$\mathrm{Zn}$ 싸이클의 열효율은 $45 \%$ 정도이며 열회수를 하지 않을 경우 최 대 $29 \%$ 정도이다. $\mathrm{ZnO} / \mathrm{Zn}$ 싸이클은 높은 에너지와 에너지효율 때 문에 가능성이 높기는 하지만 고온에서 $\mathrm{ZnO}$ 의 환원 문제를 해결해 야 하는 어려움이 있다. 또한, $\mathrm{Fe}_{3} \mathrm{O}_{4} / \mathrm{FeO}$ 싸이클이 갖는 심한 소결, 용해, 물질의 증발 특성은 싸이클 효율과 내구성을 떨어뜨리는 원 인이다. 결국 이런 열화학싸이클을 이용한 수소생산 기술의 성공여 부는 낮은 온도에서 환원이 가능하고 물분해 효율과 내구성이 높은 물질의 개발 가능성에 달려있다.

최근들어 여러 종류의 금속 페라이트 $\left(\mathrm{MFe}_{2} \mathrm{O}_{4}, \mathrm{M}=\mathrm{Co}, \mathrm{Ni}, \mathrm{Zn}\right)$ 를 이용한 연구들이 집중적으로 진행되고 있다. 이런 금속 페라이트는 순수한 $\mathrm{Fe}_{3} \mathrm{O}_{4}$ 보다 낮은 온도에서 환원되는 특성을 보여주고 그 식 은 아래와 같다.

$$
\begin{aligned}
& \mathrm{ZnFe}_{2} \mathrm{O}_{4} \rightarrow \mathrm{ZnO}+2 / 3 \mathrm{Fe}_{3} \mathrm{O}_{4}+2 / 3 \mathrm{O}_{2} \text { at } 1,800 \mathrm{~K} \\
& \mathrm{NiFe}_{2} \mathrm{O}_{4} \rightarrow \mathrm{Ni}_{y} \mathrm{Fe}_{1-y} \mathrm{O}+\mathrm{O}_{2} \text { at } 1673 \mathrm{~K} \\
& \mathrm{CoFe}_{2} \mathrm{O}_{4} \rightarrow \mathrm{CoO}+4 / 6 \mathrm{Fe}_{3} \mathrm{O}_{4}+4 / 6 \mathrm{O}_{2} \text { at } 1,673 \mathrm{~K}
\end{aligned}
$$

금속 페라이트의 환원온도는 녹는 온도에 근접하기 때문에 환원 후 소결되어 다음 물분해 싸이클에서 수소생산 속도가 떨어지는 특 성을 보여준다. 환원과정 동안 페라이트의 소결과 용해를 방지하기 위하여 1273 1673 K의 온도범위에서 소결저항이 큰 단사정계 (monclinic)의 $\mathrm{ZrO}_{2}$ 에 페라이트를 담지하여 사용하는 연구가 진행 되었다. $\mathrm{ZrO}_{2}$ 에 담지된 페라이트는 담지되지 않은 페라이트보다 상 당히 높은 수소생산 속도와 내구성을 보여주었다. 그외에도 $\mathrm{Fe}_{3} \mathrm{O}_{4}$ 의 환원온도를 낮추기 위하여 스피넬구조 페라이트가 가지는 산소 결핍점의 반응성을 이용한 연구가 진행되었으며, Ni-Mn, Ni-Zn, $\mathrm{Mn}-\mathrm{Zn}$ 의 스피넬구조 페라이트는 $1,073 \mathrm{~K}$ 에서 수소를 생산할 수 있 다는 연구결과도 발표되었다. 금속산화물과 열화학싸이클을 이용한 물분해 수소생산은 다양한 산화, 환원쌍에서 연구결과들이 발표되 고 있으나 실용화 가능성은 아직은 높지 않다. 일본의 원자력연구 소에서는 열효율이 $70 \%$ 에 이르는 $30 \mathrm{MW}$ 급 고온가스로를 보유하 고 있는데 이 시스템에서 얻은 고온열을 이용하여 열화학적 수소제 조 싸이클을 운전하고 있다. 한국에서 진행되고 있는 bench 규모의 열화학싸이클을 이용한 수소생산기술은 원자력연구원을 주축으로 에너지기술연구원과 한국과학기술연구원이 공동으로 2004 2017년 까지 추진하고 있는 "Sulfur-Iodine thermochemical water splitting cycle"이다.

\section{5. 물 전기분해 수소생산}

물전기분해법은 전력소모가 많아 고순도의 수소를 소규모로 생 산할 때 주로 이용된다. 전기분해법은 가장 오래전에 실용화된 수 소제조기술로 1900 년 초에 세계적으로 400 기 이상의 공업용 전기 분해조가 가동되었으며 1939 년에 시간 당 $10,000 \mathrm{Nm}^{2}$ 의 수소를 생 산할 수 있는 대규모의 전해시설이 가동되었다. 1948년에는 가압형 전해조가 건설되었으며 1966년에 처음으로 고체고분자 전해질 전 해시스템이 GM에 의해 개발되었고, 1971년 고온수증기를 이용한 물전기분해 연구개발이 시작되었다. 현재 상업적으로 개발되어 사 용되는 방법은 알칼리전해질을 이용한 물전기분해 기술이다.

알칼리수전해의 경우 음극에서 수소가 양극에서 산소가 2:1의 비 율로 생산되며 Fig. 5와 같이 수산기가 격막을 통해 양극으로 전달 되어 산소가 발생된다. 수소가 발생되는 환원반응은 2 개의 양성자

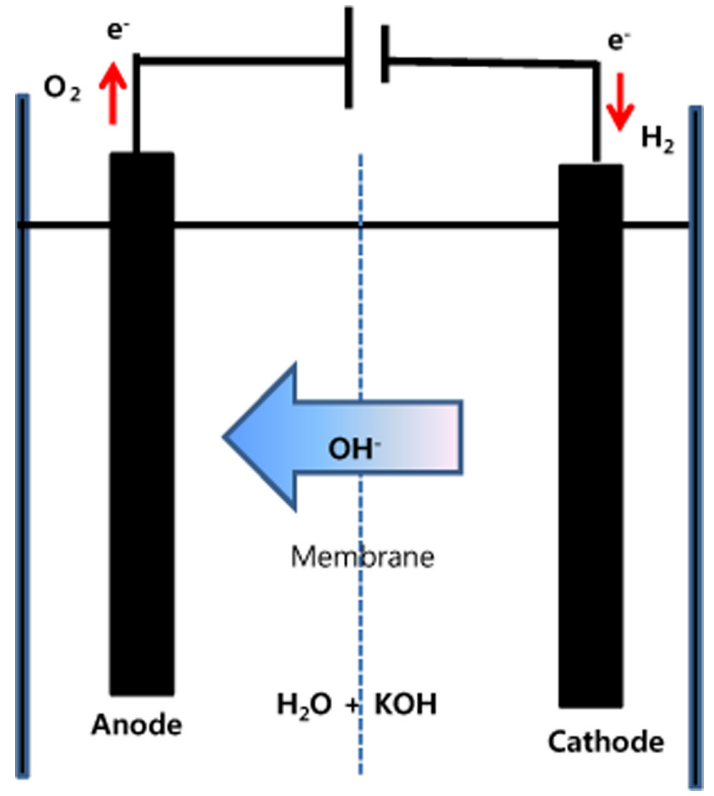

Fig. 5. Alkaline electrolysis system.

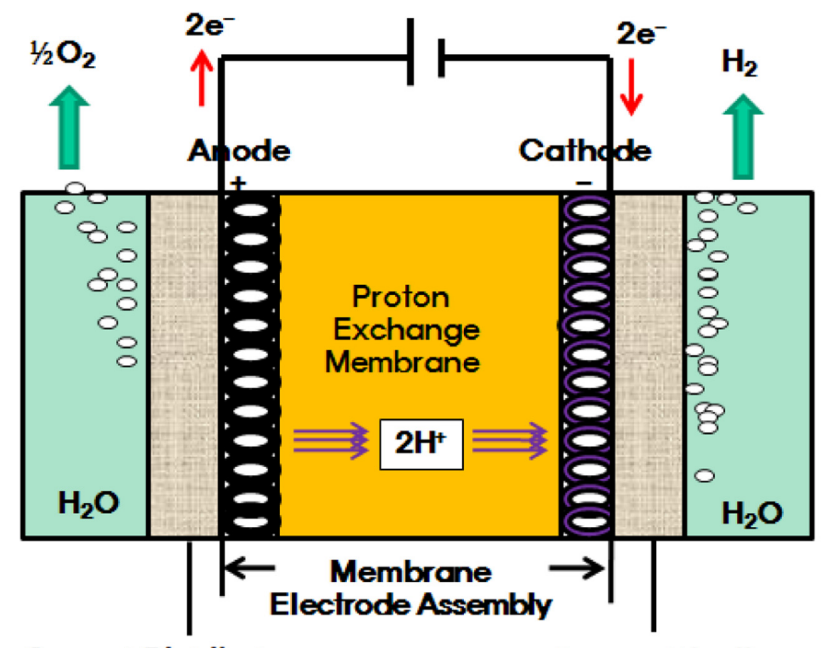

Current Distributor

Current Distributor

Fig. 6. PEM(polymer electrolyte membrane) electrolyzer.

가 2 개의 전자를 받아 진행되며 양극에서는 2 개의 수산기가 2 개의 전자를 내 놓고 반개의 산소분자와 1 분자의 물을 생성한다. 알칼리 전해조에는 단극식과 양극식이 있으며 단극식의 경우 전극이 평행 으로 연결되어 있어 설치보수가 간단하며 낮은 온도와 낮은 전류밀 도에서 작동된다. 양극식의 경우 음극과 양극의 전극이 교차 설치 되며, 전지는 병렬로 연결되고 높은 전류밀도와 고압에서의 작동이 가능하지만 보수가 어려운 단점이 있다. 물의 열역학적 분해 전압 은 $1.23 \mathrm{eV}$ 이지만 전해조와 그 회로에 존재하는 저항 때문에 실재 로는 더 높은 전압이 필요하게 된다. 전해조의 연결회로에는 전기 전항이 있으며 용액 내부에는 기포의 생성이나 이온의 이동과 관련 된 전달관련저항이 존재하며 전기화학반응저항도 상당하다. 이런 저항들을 낮추기 위해서 운전온도와 전압을 높일 필요가 있다. 수 소생산 속도는 전해질의 종류, 농도, 전극안정성, 및 운전 전류밀도 와 관련이 있으며 알칼리 전해조의 경우 $~ 0.3 \mathrm{~A} / \mathrm{cm}^{2}$ 의 전류밀도가 적용될 수 있다. 
고분자 전해질 물전기분해의 경우 알칼리 수전해보다 에너지효 율이 높으며 그 이론효율은 80 90\%에 달한다. 높은 전류밀도에서 운전이 가능하며 작동전압을 수 백 bar까지 설계가능하지만 고가의 고분자막과 다공성전극 및 집전장치가 요구된다. 고분자 전해질막 의 내구성이 짧아 일반적용도에 사용하기에는 너무 고가이며 현재 는 낮은 용량 $(0.9 \mathrm{~kg} / \mathrm{hr})$ 에서만 상용화되었다. Fig. 6은 고분자 전해 반응을 보여 주고 있으며 주입되는 물이 분해되어 산소가 발생하고 생성된 양성자는 양이온교환막을 통해 음극으로 이동하여 수소가 발생하게 된다. 높은 전류밀도 $\left(\sim 1 \mathrm{~A} / \mathrm{cm}^{2}\right)$ 를 사용하기 때문에 효율 적으로 물을 분해하기 위하여 급전체를 이용하고 양성자의 이동저 항을 줄이기 위해 산화, 환원전극과 양이온 교환막은 저항이 낮은 상태에서 접촉되어 있어야 한다.

그 외에도 이온의 이동을 위해 사용하는 알칼리 전해질 대신 고 체산화물을 전해질로 사용하여 고온에서 물을 분해하는 기술이 연 구되고 있다(Fig. 7). 반응온도는 820 1,073 K 정도이며 종래의 저 온 물분해보다 전기에너지소모가 적으며 전류밀도는 $~ 0.7 \mathrm{~A} / \mathrm{cm}^{2}$ 로 유지할 수 있으며 스팀온도는 $1,073 \mathrm{~K}$ 이다. 고온수전해 기술의 경 우 전해조의 재료, 안전, 엄격한 온도제어가 요구되며 고온에서 작 동하는 고체전해질의 개발이 필요하다. 각 기술별 효율 및 특성을 Table 4에 나타내었다. 가격과 신뢰성은 알칼리 수전해가 가장 우수 하지만 효율이 다소 낮은 단점이 있다.

물분해 수소제조 분야의 연구동향을 살펴보면 다음과 같다. 알칼 리수전해의 경우, 알칼리 전해질의 농도를 $40 \%$, 운전 압력 $40 \mathrm{bar}$, 전류밀도 $0.2 \sim 2 \mathrm{~A} / \mathrm{cm}^{2}$ 에서 효율을 80 90\%까지 증가시킨 연구결과 들이 발표되고 있다. 고체고분자 전해질 시스템의 경우 최근에 대 용량이 개발되고 있으며 미국의 Hogen사에서 수소생산속도 $10 \mathrm{Nm}^{3} / \mathrm{hr}$, 전해전압 15 기압의 제품을 생산하였으나 전해효율이 낮 은 것으로 발표되었다. 미국은 고압 알칼리수전해와 고분자전해질

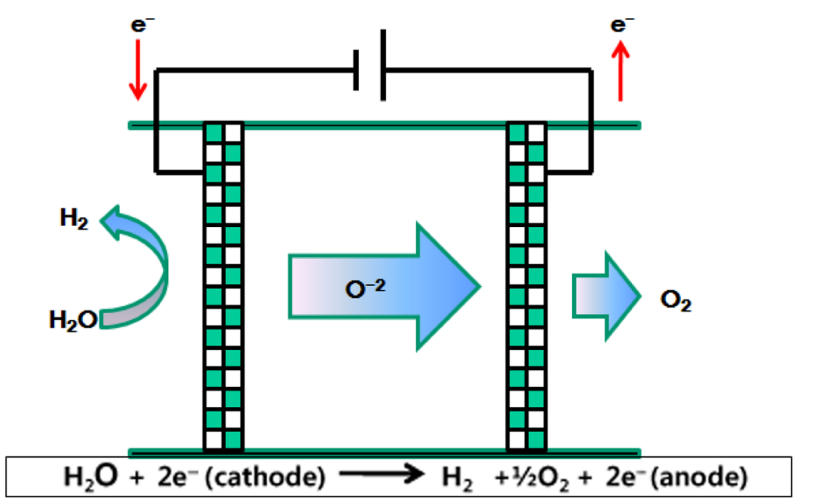

Fig. 7. High temperature electrolyzer.

Table 4. Efficiencies and properties of three electrolyzers

\begin{tabular}{lccc}
\hline \hline \multicolumn{1}{c}{ Division } & $\begin{array}{c}\text { Alkali aqueous } \\
\text { solution }\end{array}$ & $\begin{array}{c}\text { Polymer } \\
\text { electrolyte }\end{array}$ & $\begin{array}{c}\text { High } \\
\text { temperature } \\
\text { water vaper }\end{array}$ \\
\hline Operation temperature & $\leqq 80^{\circ} \mathrm{C}$ & $\leqq 80^{\circ} \mathrm{C}$ & $700^{\circ} \mathrm{C} \leqq$ \\
Current density & $\leqq 0.3 \mathrm{~A} / \mathrm{cm}^{2}$ & $1 \mathrm{~A} / \mathrm{cm}^{2} \leqq$ & $1 \mathrm{~A} / \mathrm{cm}^{2} \leqq$ \\
Energy Electricity & Large & Medium & Small \\
consumption Heat & Small & Small & Large \\
Price & Small & Large & Medium \\
Credibility & Large & Medium & Small \\
\hline
\end{tabular}

J. Korean Ind. Eng. Chem., Vol. 19(4), 2008, Jaeyoung Lee
수전해 장치 및 저렴한 전해장치를 개발하는 연구를 진행하고 있다. 일본은 WE-NET project에서 단위셀 면적 $2,500 \mathrm{~cm}^{2}, 1$ 기압, $80^{\circ} \mathrm{C}$, $1 \mathrm{~A} / \mathrm{cm}^{2}$ 에서 운전되는 5 단 스택을 개발하였으며 그 효율은 $94.4 \%$ 라고 발표하였다. 고분자전해질 수전해의 경우 귀금속전극을 사용 해야 하는 단점이 있으며 이를 대체하기위한 연구들이 진행되고 있 다. 독일 Ulm 대학에서는 금과 팔라듐 결정성과 표면상태에 따른 수소발생능 관련연구가 진행되었으며 덴마크의 Norskov팀에서는 합금으로 조합한 전극목록을 발표하였다. 한국은 프론티어 수소사 업단에서 고체고분자 전해질을 이용한 수전해 $\left(3 \mathrm{Nm}^{3} / \mathrm{hr}\right)$ 와 고온 수 증기법 $\left(50 \mathrm{~L} / \mathrm{hr}, 700{ }^{\circ} \mathrm{C}\right)$ 을 연구하고 있다.

\section{6. 태양광을 이용한 물분해 수소생산}

지구상의 $70 \%$ 이상을 차지하는 물은 에너지를 공급받으면 $\left(\mathrm{E}_{1}\right)$ 산소와 수소로 분리되며(Fig. 8), 생산된 수소는 에너지를 공급하면 서 $\left(\mathrm{E}_{2}\right)$ 물을 배출하게 된다. 그런데 수소를 생산하기 위해 필요한 에너지인 $\mathrm{E}_{1}$ 이 수소가 공급하는 에너지인 $\mathrm{E}_{2}$ 보다 크기 때문에 $\mathrm{E}_{1}$ 을 재생에너지에서 공급받아야 수소가 대체에너지원으로 의미를 갖는 다. 수소에너지 순환경로는 Fig. 8에 나타내었다.

태양에너지는 전자기파 $(300 ~ 2,100 \mathrm{~nm})$ 형태로 지구로 입사되기 때문에 이를 이용하기 위해서는 필요에 맞는 적절한 에너지형태로 전환되어야 한다. 태양에너지는 열이나 전기에너지로 전환하여 사 용할 수 있지만 이 경우 저장하여 이용하는데 문제가 있다. 그래서 태양에너지를 저장과 운송이 용이한 화학에너지로 직접 전환하여 사용하기위한 연구들이 진행되고 있다. 태양에너지를 이용해 물로 부터 수소를 생산하는 기술은 1. 전기를 만든 후 물 전기분해, 2. 직 접 물분해, 3. 광촉매를 이용한 물분해, 4. 광생물학적방법을 이용한 물분해, 5. Non- $\mathrm{O}_{2}$ (예: 산소발생 과전압이 높기 때문에 $\mathrm{H}_{2} \mathrm{~S}$ 를 이용 해 수소와 황을 생산하는 반응) 발생 시스템을 이용한 수소생산 등 이 있다. 태양광을 이용하여 물로부터 수소를 생산하는 기술은 열 적전환이나 전기로 만든 후 전기분해하는 과정에 포함될 수 있는 효 율저하 요인이 배제되기 때문에 태양에너지를 이용하는 기술중에서 가장 가능성이 높다. 순수한 물은 solar radiation을 흡수하지 않기 때문에 태양광을 흡수할 수 있는 물질이 요구된다. 태양광전환효율 은 사용하는 반도체 또는 광촉매의 특성에 의해 결정된다. 대부분 의 반도체 물질은 빛을 흡수하여 활성화된 전자를 생성할 수 있고

\section{Hydrogen Energy Cycle}
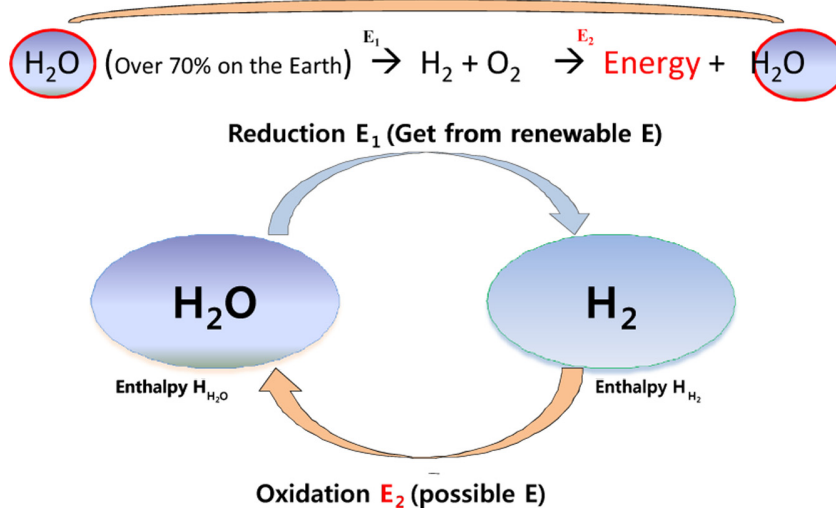

Fig. 8. Cycle of hydrogen energy. 


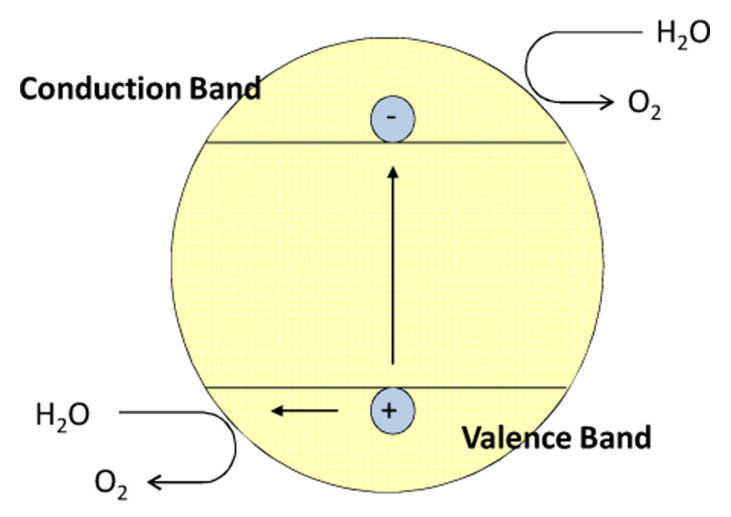

Fig. 9. $\mathrm{H}_{2}$ production on photocatalyst from $\mathrm{H}_{2} \mathrm{O}$.

흡수된 태양에너지를 가진 전자는 물을 분해하여 수소를 생산할 수 있게 된다. 물을 분해하여 수소를 생산하기 위해서는 물분해 산화, 환원 전위를 포함하는 띠간격에너지(band gap energy)를 가지는 반 도체 물질을 광촉매로 사용해야 한다. Fig. 9는 광촉매의 전도대와 가전자대에서 일어나는 산화, 환원반응을 보여준다. 광촉매에 의한 수소제조 기술은 고활성 광촉매 소재개발에 치중하여 진행되었으며, 촉매조성 및 제조방법, 금속첨가물활용, 광감응제 복합활용 등을 통 해 최적의 물리화학적 구조설계 및 합성을 시도하였다. 주로 자외 광 활용 광촉매 개발이 주류를 이루고 있으며 일본의 도멘교수는 델 라포사이트와 가시광을 활용하여 $3 \mu \mathrm{mol} \mathrm{H} / \mathrm{hrg}_{\text {cat }}$ 의 속도로 수소 를 생산할 수 있다고 발표하였다. 광촉매를 활용한 수소생산속도는 자외광이용 광촉매의 경우 $1,000 \mu \mathrm{mol} \mathrm{H} / \mathrm{hrg}_{\text {cat }}$ 이하이고, 추가 금 속첨가제 또는 증진제를 활용할 경우 $50,000 \mu \mathrm{mol} \mathrm{H} / \mathrm{hr}_{\mathrm{g}}$ cat 이하, 가시광 이용광촉매의 경우 $10 \mu \mathrm{mol} \mathrm{H} / 2 / \mathrm{hrg}_{\text {cat }}$ 이하이다.

반도체물질이 빛을 흡수하면 가전자대(valence band)에 있는 전 자가 태양광을 흡수하여 전도대(conduction band)로 여기되고 이 전 자가 양성자와 만나게 되면 수소가 생성된다. 여기된 전자가 양성 자와 만나기 위해서는 물질내부에서 이동해야 하는데 전자의 이동 이 충분히 빠르지 않으면 가전자대의 정공과 재결합하면서 흡수한 태양에너지를 빛이나 열로 소실하게 된다. 입자형태로 사용하는 광 촉매의 경우 전자가 빠르게 이동할 수 있도록 해주는 추진력이 크 지 않아 전도대로 여기된 전자의 대부분이 재결합되어 광효율을 높 이는데 한계가 있다. 반도체 물질을 이용한 박막전극 제조 후 광전 기화학전지를 구성할 경우 전해질과 접촉한 전극내부에 강한 전기 장이 형성되어 전도대로 여기된 전자가 빠르게 이동할 수 있는 추 진력이 형성되어 전자-정공의 재결합이 방지되어 이론 효율이 $32 \%$ 까지 크게 증가한다. 광전기화학전지는 n형 반도체물질로 구성된 양극과 백금과 같은 귀금속을 음극으로 하여 외부회로로 연결되어 수용액전해질에 침지시켜 사용할 수 있다. 이런 전지를 구성할 경 우 전도대로 여기된 전자의 재결합은 크게 줄일 수 있지만 전극구 성에 따른 저항, 전해질에서의 이온의 이동 및 전기화학반응에서 오 는 저항등으로 실재 열역학적으로 필요한 전위보다 높은 물분해 전 위가 필요하다. Fig. 10 은 광전기화학전지의 구성도를 보여주고 있 다. 1972년 일본의 후지시마등이 광전기화학전지를 이용한 물분해 연구결과를 발표한 후 많은 연구자들이 이 분야의 연구를 수행하고 있으나 아직 괄목할 만한 연구성과는 나오지 않고 있다. 대부분의 연구결과들이 전극표면에서 측정되는 전류로 태양광-수소효율을 발 표하고 있으며 실제로 발생하는 수소를 측정하여 효율을 계산한 경

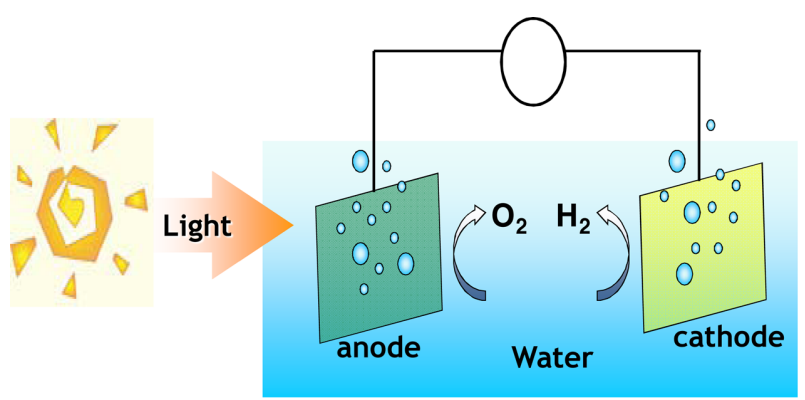

A Monolithic Photoelectrochemical Cell

Fig. 10. Photoelectrochemical cell.

우는 많지 않다. 일반적으로 생성물의 양은 흐르는 전류의 양에 비 례하지만 물분해의 경우 물 분해에 충분한 전압을 가지지 않은 전 류는 아무리 많이 흘러도 수소생산에 기여할 수 없는 사실을 간과 하기 쉅다.

태양에너지를 흡수한 반도체물질이 낼 수 있는 전위의 크기는 반 도체물질의 띠간격 에너지에 영향을 받으며 띠간격에너지가 클수록 얻어지는 전위 값은 크다. 띠간격에너지보다 큰 태양광을 흡수한 반 도체 전극 물질의 전도대로 여기된 전자가 가진 에너지는 $75 \%$ 만 내부에너지이며 나머지 $25 \%$ 는 엔트로피증가에 사용되는 에너지이 다. 그래서 반도체물질이 태양광을 흡수하여 얻는 $\mathrm{V}_{o c}$ (개방전압)는 대부분 반도체물질의 띠간격에너지보다 작은 값을 나타낸다. 사용 하는 반도체전극의 가전자대와 전도대의 전위가 물의 산화환원 전 위를 포함하고 물분해에 충분한 띠간격에너지를 가지더라도,단일 전극으로 구성된 광전기화학전지에서 수소를 발생하기 어려운 것은 실재로 얻어지는 개방전압이 물분해에 충분하지 않기 때문이다. 광 전기화학전지를 이용하여 물을 분해하기 위해서는 전극을 직렬이나 탄뎀형태로 연결하여 산소발생에 필요한 과전위(over potential)를 포함한 충분한 전압을 얻을 수 있어야 한다. 또한, 전통적인 형태의 광전기화학 전지에서는 태양광을 흡수하는 전극을 수용액속에 침지 하는데 이 경우 전극의 광부식이 심하고 전극표면에 생성된 기포가 태양광의 흡수를 방해하기 때문에 태양광-수소효율을 감소시키는 원인이 될 수 있다. 광전기화학전지를 이용한 수소는 미국에서 주 로 연구되고 있으며 염료감응태양전지를 개발한 그래첼팀에서 태양 광-수소효율 $5 \%$ 의 직렬연결형(염료감응태양전지와 산화물반도체 를 직렬 연결함) 셀을 발표한 적이 있다. 또한, $\mathrm{DOE}$ 의 지원을 받는 Toledo대학과 midwest optoelectronics에서 무정질실리콘 탄뎀셀을 전해질 외부에 설치하여 $5 \%$ 의 태양광-수소효율을 발표하였다.

\section{7. 결 론}

전 세계적으로 화석연료가 아닌 재생에너지원을 이용한 수소생 산 기술 개발에 많은 나라가 참여하고 있으며 연료전지의 개발과 함 께 앞으로도 많은 연구가 진행될 것이다. Table 5 는 현재까지 진행 되고 있는 수소개발 프로그램과 관련 국가들을 보여주고 있다. 많 은 노력에도 불구하고 앞으로도 상당히 오랜 기간 동안 수소는 화 석연료 기반으로 제조될 것으로 전망되고 있으며 현재 연구 개발되 고 있는 기술들이 기존의 화석연료 기반 기술보다 경쟁우위를 가지 려면 화석연료가 가지는 장점들을 극복할 수 있어야 한다. Table 6 은 2020 년에 수소공급가격을 예측한 결과로 천연가스를 증기개질 
Table 5. $\mathbf{H}_{2}$ development programs and the nations

\begin{tabular}{ll}
\hline \hline Hydrogen development Program & Related countries \\
\hline DOE Hydrogen E. Program & USA, In some European countries \\
WE-NET & Japan, European countries \\
Euro-Quebec & Canada, European Union \\
IEA-Hydrogen Program & USA, Japan, Canada, Germany, \\
Annex-1-15 & European Union \\
Norway-Germany & Norway, Germany \\
HY_SOLAR & Germany, Saudi Arabia \\
Space-station & Multinational Program \\
German Hydrogen project & Germany \\
\hline
\end{tabular}

WWW.EHIP.org/European Integrated Hydrogen Project

Table 6. Estimated $\mathrm{H}_{2}$ cost at 2030

\begin{tabular}{lc}
\hline \hline $\mathrm{H}_{2}$ production method & Supply Cost (US\$/GJ) \\
\hline Natural Gas with CCS & $7 \sim 11$ \\
Coal with CCS & $8 \sim 11$ \\
Biomass(gasification) & $10 \sim 18$ \\
Onshore wind & $17 \sim 23$ \\
Offshore wind & $22 \sim 30$ \\
Thermal solar electricity & $27 \sim 35$ \\
Solar PV & $47 \sim 75$ \\
Nuclear & $15 \sim 20$ \\
HTGR cogeneration & $10 \sim 25$ \\
Gasoline/diesel(conventional) & $6 \sim 8$ \\
Natural gas(conventional) & $3 \sim 5$ \\
\hline
\end{tabular}

B. Kroposki, NREL Technical Report(2006)

할 경우 가장 값싼 수소를 얻을 수 있다는 것을 알 수 있다. 또한 현 재 기술개발이 진행되고 있는 재생에너지원을 이용한 수소생산 기 술의 경우 2020 년에도 화석연료기반의 수소생산기술과 비교해서 경제성을 확보하기 어렵다는 것을 예측할 수 있다.

\section{참고문헌}

1. Ball, M. and Wietschel, M., "The Future of Hydrogen-opportunities and Challenges,' Int. J. Hydrogen Energy, 34, 615-627 (2009).

2. Crabtree, R.(Ed.), Energy Production and Storage: Inorganic Chemical Strategies for a Warming World, Wiley, 3-20(2010).

3. Melis, A., "Solar Energy Conversion Efficiencies in Photosynthesis: Minimizing the Chlorophyll Antennae to Maximize Efficiency,' Plant Science, 177, 272-280(2009).

4. McConnell, I., Li, G. and Brudvig, G. W., "Energy Conversion in Natural and Artificial Photosynthesis,' Chem. Biol., 17, 434-447 (2010).

5. Allakhverdiev, S. I., Thavasi, V., Kreslavski, V. D., Zharmukhamedov, S. K., Klimov, V. V., Ramakrishna, S., Los, D. A., Miruto, M., Nishihara, H. and Carpentier, R., "Photosynthetic Hydrogen Production,' J. Photochem. Photobio. C: Photochemistry reviews, 11, 87-99(2010).

6. Kim J., Hydrogen production technology trends, Korea Institute of Science and Technology Information(KISTI)(2004).

7. A study on high production technologies and economical estima- tion of hydrogen fuel, KIER-991417, 12(1999).

8. Kim, S. J., Biological hydrogen production technology-present condition and vision, Sungkyunkwan University(2005).

9. Park, J. W., Kim, J. M. and Yih, W. H., "Current Status of pHotobiological Hydrogen Production Technology Using Unicellular Marine Cyanobacterial Strains,' J. Kor. Soc. of Oceanopraphy, 14(1), 63-68(2009).

10. Gim, B. J. and Kim, J. W., "Economic Evaluation of Domestic Photobiological Hydrogen Production,', Transactions of the Korean Hydrogen and New Energy Society, 19(4), 322-330(2008).

11. Lee, J., Yi, Y. and Uhm, S., "Understanding Underlying Process of Water Electrolysis,' J. Korean Ind. Eng. Chem., 19(4), 357-365 (2008).

12. Lee, H.-S., Vermaas, W. F. J. and Rittmann, B. E., "Biological Hydrogen Production: Prospectives and Challenges,' Trends in Biotechnology, 28(5), 262-271(2010).

13. Tributsch, H., "Photovoltaic Hydrogen Generation,' Int. J. Hydrogen Energy, 33, 5911-5930(2008).

14. Palumbo, R., Lede, J., Boutin, O., Elorza Ricart, E., Steinfeld, A., Moller, S., Weidenkaff, A., Fletcher, E. A. and Bielicki, J., "The Production of $\mathrm{Zn}$ from $\mathrm{ZnO}$ in a High-temperature Solar Decomposition Quench Process-I. The Scientific Framework for the Process,' J. Chem. Eng. Sci., 53(14), 2503-2517(1998).

15. Stenfield, A., "Solar Hydrogen Production Via a Two-step Watersplitting Thermochemical Cycle Based on $\mathrm{Zn} / \mathrm{ZnO}$ Redox Reactions,' Int. J. Hydrogen Energy, 27(6), 611-619(2002).

16. Kodama, T., Kondoh, Y., Yamamoto, R., Andou, H. and Sator, N., "Thermochemical Hydrogen Production by a Redox System of $\mathrm{ZrO}_{2}$-supported Co(II)-ferrite,' Solar Energy, 78, 623-631(2005).

17. Miller, J. E., Allendorf, R. B., Diver, L. R. Evans, Siegel, N. P. and Strecker, J. N., "Metal Oxide Composites and Structures for Ultra-high Temperature Solar Thermochemical Cycles,' J. Mater. Sci., 43, 4714-4728(2008).

18. Kodama, T., Gokon, N. and Yamamoto, R., "Thermochemical Two-step Water Splitting by $\mathrm{ZrO}_{2}$-supported $\mathrm{NixFe}_{3-x} \mathrm{O}_{4}$ for Solar Hydrogen Production,' Solar Energy, 82, 73-79(2008).

19. Kaneko, H., Kodama, T., Gokon, N., Tamaura, Y., Lovegrove, K. and Luzzi, A., "Decomposition of $\mathrm{Zn}$-ferrite for $\mathrm{O}_{2}$ Generation by Concentrated Solar Radiation,' Solar Energy, 76, 317-322(2004).

20. Gokon, N., Mizuno, T., Nakamuro, Y. and Kodama, T., "Iron-Containing Yttria-Stabilized Zirconia System For Two-Step Thermochemical Water Splitting,' J. Solar Energy Eng., 130(1), 0110181 011018-6(2008).

21. Miller, E. L., Rocheleau, R. E. and Deng, X. M., "Design Considerations for a Hybrid Amorphous Silicon/photoelectrochemical Multijunction Cell for Hydrogen Production,', Int. J. Hydrogen Energy, 28, 615-623(2003).

22. Xu, L., Garland, R. and Elam, C., "Critical Research for CostEffective Photoelectrochemical Production of Hydrogen,' FY 2006 Annual progress report, 149-153(2006).

23. Light, S., "2006 Energy Technology Research Award Address: Photoelectrochemical Storage of Solar Energy,' Electrochemical Society Transactions, 2(28), 1-14(2007).

24. Graetzel, M. and Augustinki, J., "Tandem Cell for Water Cleavage by Visible Light', US 6,936,143 B1(2005). 